\title{
Effects of Composition and Thermal Treatment of Cu-Al-Zn Alloys with Low Content of Al on their Shape-memory Properties
}

\author{
Zorica Stošića , Dragan Manasijevića *, Ljubiša Balanovića, Tamara Holjevac-Grgurićb, Uroš \\ Stamenkovića, Milena Premovićc, Duško Minićc, Milan Gorgievski ${ }^{a}$, Radiša Todorovićd \\ ${ }^{a}$ Technical Faculty, University of Belgrade, Bor, Serbia \\ ${ }^{b}$ Faculty of Metallurgy, University of Zagreb, Sisak, Croatia \\ ${ }^{c}$ Faculty of Technical Sciences, University of Priština, Kosovska Mitrovica, Serbia \\ ${ }^{d}$ Institute of Mining and Metallurgy, Bor, Serbia
}

Received: January 25, 2017; Revised: June 10, 2017; Accepted: July 21, 2017

\begin{abstract}
Two Cu-Zn-Al alloys with variable content of $\mathrm{Zn} \mathrm{(25}$ and $30 \mathrm{wt} \%$ ) and constant Al content (4 $\mathrm{wt} \%$ ) prepared by induction melting of pure metals and hot rolled into strips of $0.5 \mathrm{~mm}$ thickness were thermally processed by using three different heat treatments: direct quenching, step-quenching and upquenching with boiling water and room temperature water as the quenchants. The effects of composition and different methods of heat treatment on the microstructure and transformation temperatures of the investigated $\mathrm{Cu}-\mathrm{Zn}-\mathrm{Al}$ alloys were investigated using SEM-EDS and DSC techniques.
\end{abstract}

Keywords: Shape memory alloy, Cu-Zn-Al system, Microstructure, DSC.

\section{Introduction}

Shape memory alloys (SMAs) are group of alloys which can recover their shape when they are heated above a certain temperature ${ }^{1}$. The shape memory effect is based on martensitic transformation (MT) which is a diffusionless and reversible phase transformation ${ }^{2-4}$. It occurs between the high-temperature austenite phase $(\beta)$ and the low-temperature martensite phase $\left(\beta^{\prime}\right)^{3-4}$.

It is well known that many copper alloys such as $\mathrm{Cu}$ $\mathrm{Al}, \mathrm{Cu}-\mathrm{Zn}-\mathrm{Al}, \mathrm{Cu}-\mathrm{Al}-\mathrm{Ni}$ and $\mathrm{Cu}-\mathrm{Al}-\mathrm{Mn}$ exhibit shape memory properties ${ }^{5-7}$. Cu-based SMAs have attracted much attention due to their good shape memory capacity, narrow temperature region of transformation, ease of fabrication and low production $\operatorname{cost}^{8}$.

For the alloys of the ternary $\mathrm{Cu}-\mathrm{Zn}-\mathrm{Al}$ system, the shape memory effect is only observed within a certain range of composition which generally contains 16 to $30 \%$ of $\mathrm{Zn}$ and 4 to $8 \%$ of $\mathrm{Al}^{3}$. Depending on alloy composition and temperature, three equilibrium phases ( $\alpha, \beta$ and $\gamma$ ) may occur. However, $\beta$ phase is the only phase that exhibits the shape memory effect of practical importance. The $\beta$ phase in the $\mathrm{Cu}-\mathrm{Zn}-\mathrm{Al}$ alloys is disordered at high temperatures and has a bcc lattice ${ }^{3,4}$. During the cooling process and depending on the alloy composition the parent $\beta$-phase can order in two different superlattice structures $\beta_{2}$ (B2) and $\beta_{3}$ (L21) ${ }^{3,4}$. By stress-induced or thermally, the $\beta_{2}$ or $\beta_{3}$ austenite phases transform into the $\beta_{2}$ ' or $\beta_{3}^{\prime}$ martensitic phases ${ }^{3,4}$. Cu-Zn-Al alloys are usually quenched to retain the $\beta$ phase for further transformation to martensite?
In this work the shape memory characteristics of two $\mathrm{Cu}-\mathrm{Zn}-\mathrm{Al}$ alloys with constant content of aluminium (4 wt.\%) and variable content of zinc ( 25 and 30 wt.\%) were studied. Thus, the focus of the current study was on the $\mathrm{Cu}-\mathrm{Zn}$-Al SMAs with low content of aluminium. Effects of composition and thermal processing on the microstructure and transformation temperatures of the investigated alloys were investigated using SEM-EDS and DSC.

\section{Experimental Procedure}

Two $\mathrm{Cu}-\mathrm{Zn}-\mathrm{Al}$ alloys with the nominal compositions $\mathrm{Cu}-25 \% \mathrm{Zn}-4 \% \mathrm{Al}$ and $\mathrm{Cu}-30 \% \mathrm{Zn}-4 \% \mathrm{Al}$ were prepared by induction melting of calculated quantities of pure (99.9\%) copper, zinc and aluminium under a charcoal cover. The alloys were cast into graphite moulds and ingots in the form of cylindrical bars with about $1 \mathrm{~cm}$ diameter and 10 $\mathrm{cm}$ length were produced. The ingots were hot rolled into $0.5 \mathrm{~mm}$ thick strips (Fig. 1).

Heat treatments of prepared $\mathrm{Cu}-\mathrm{Zn}$-Al strips included $\beta$-solutionizing at $850^{\circ} \mathrm{C}$ for 30 minutes followed by:

1) direct quenching into room temperature water;

2) up-quenching - quenching into room temperature water with subsequent ageing at $100^{\circ} \mathrm{C}$ for 30 minutes before quenching again into water at room temperature;

3) step-quenching - quenching into boiling water at $100^{\circ} \mathrm{C}$, remaining at this temperature for 15 minutes and finally cooled in room temperature water;

Samples used for the scanning electron microscopy (SEM) observations were mechanically grinded and polished.

* e-mail: dmanasijevic@mts.rs 


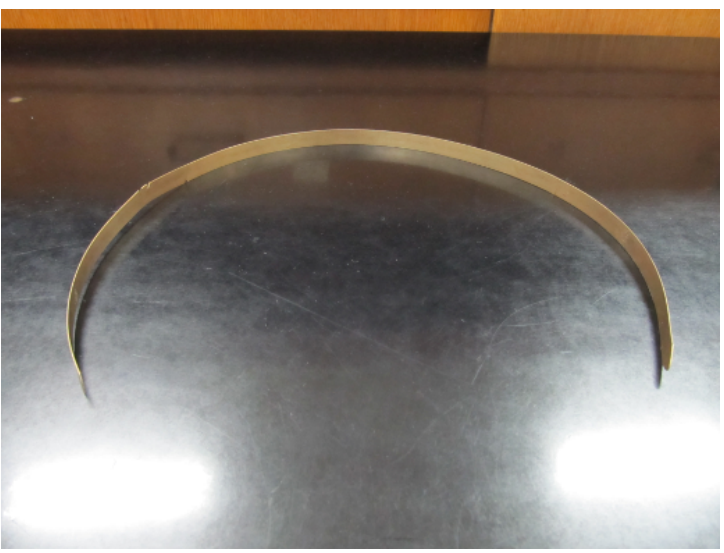

Figure 1. Investigated $\mathrm{Cu}-25 \% \mathrm{Zn}-4 \% \mathrm{Al}$ alloy strip.

Subsequently, they were etched with a solution containing $2.5 \mathrm{~g} \mathrm{FeCl}_{3} \cdot 6 \mathrm{H}_{2} \mathrm{O}$ and $1 \mathrm{ml} \mathrm{HCl}$ in $48 \mathrm{ml}$ methanol.

TESCAN VEGA3 scanning electron microscope with energy dispersive spectroscopy (EDS) (Oxford Instruments $\mathrm{X}$-act) was used for microstructure investigation of the prepared alloys and the analysis was carried out at $20 \mathrm{kV}$. Overall compositions and compositions of coexisting phases were determined using EDS area and point analysis.

Overall chemical compositions of the investigated $\mathrm{Cu}-\mathrm{Zn}$ $\mathrm{Al}$ alloys in the as-cast state and after heat treatments were checked using EDS area analysis. Experimentally determined compositions of the investigated alloys $(\mathrm{Cu}-24.9 \pm 0.5 \mathrm{Zn}$ $4.1 \pm 0.2 \mathrm{Al}$ and $\mathrm{Cu}-30.0 \pm 0.4 \mathrm{Zn}-4.2 \pm 0.3 \mathrm{Al}$ (in wt.\%)) were in good agreement with their nominal compositions.

Transformation temperatures were determined by SDT Q600 (TA Instruments) simultaneous DSC/TGA analyzer. DSC measurements were done in argon atmosphere through

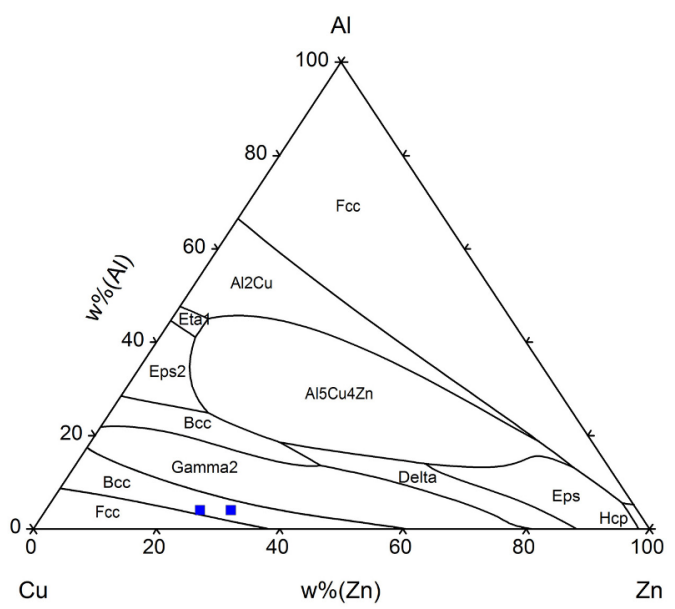

(a)
3 heating runs from room temperature to $100^{\circ} \mathrm{C}$ with heating rate $5{ }^{\circ} \mathrm{C} / \mathrm{min}$.

Martensitic transformation temperatures for directly quenched sample were studied on DSC analyzer Mettler Toledo 822e. Measurements were done in inert atmosphere, through 2 heating/cooling cycles from -50 to $200{ }^{\circ} \mathrm{C}$ with heating/cooling rates $10^{\circ} \mathrm{C} / \mathrm{min}$.

\section{Results and Discussion}

\subsection{Phase equilibria calculations}

Fig. 2 shows liquidus projection and phase diagram at $800^{\circ} \mathrm{C}$ of the $\mathrm{Cu}-\mathrm{Zn}$-Al system calculated using optimized thermodynamic parameters from Liang and Schmid-Fetzer ${ }^{10}$ and Pandat software ${ }^{11}$ with marked overall compositions of the $\mathrm{Cu}-25 \% \mathrm{Zn}-4 \% \mathrm{Al}$ and $\mathrm{Cu}-30 \% \mathrm{Zn}-4 \% \mathrm{Al}$ alloys investigated in this study.

From Fig. 2a it can be seen that overall compositions of both investigated alloys belong to the primary crystallization field of $\beta$ (Bcc) phase.

Also, according to the calculated phase diagram of the $\mathrm{Cu}-\mathrm{Zn}$-Al ternary system at $800{ }^{\circ} \mathrm{C}$ presented in Fig. 2b, overall compositions of both investigated alloys are situated in the single $\beta$ (Bcc) phase region although the composition of the $\mathrm{Cu}-25 \% \mathrm{Zn}-4 \% \mathrm{Al}$ is very close to the $\alpha+\beta(\mathrm{Fcc}+\mathrm{Bcc})$ two-phase region.

\subsection{Microstructures of as-cast alloys}

Microstructures and phase compositions of the $\mathrm{Cu}-25 \% \mathrm{Zn}$ $4 \% \mathrm{Al}$ and $\mathrm{Cu}-30 \% \mathrm{Zn}-4 \% \mathrm{Al}$ alloys in the as-cast states (ingot samples) were investigated using SEM-EDS. Based on the obtained results it was determined that as-cast $\mathrm{Cu}-25 \% \mathrm{Zn}$ -

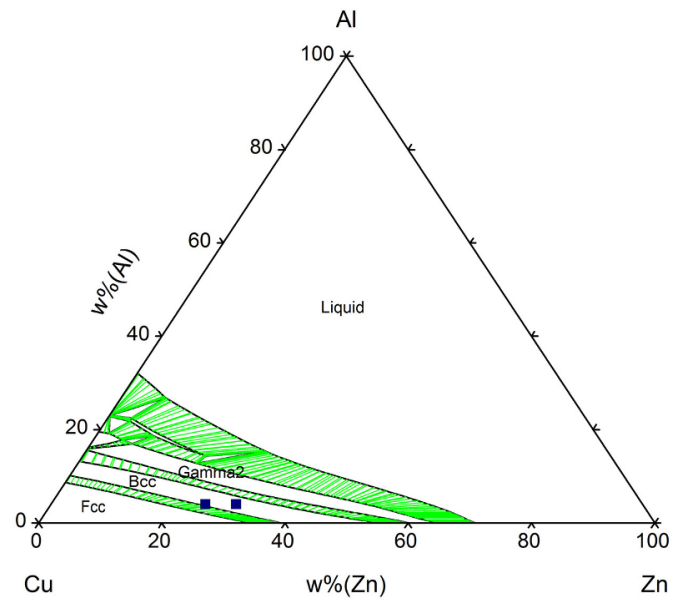

(b)

Figure 2 . Calculated phase equilibria of the $\mathrm{Cu}-\mathrm{Zn}-\mathrm{Al}$ ternary system using optimized thermodynamic parameters from Liang and Schmid-Fetzer ${ }^{10}$ with marked overall compositions (squares) of the investigated $\mathrm{Cu}-25 \% \mathrm{Zn}-4 \% \mathrm{Al}$ and $\mathrm{Cu}-30 \% \mathrm{Zn}-4 \% \mathrm{Al}$ alloys: (a) liquidus projection; (b) phase diagram at $800{ }^{\circ} \mathrm{C}$. 
$4 \% \mathrm{Al}$ alloy has two-phase $\alpha+\beta$ (Fcc $+\mathrm{Bcc})$ microstructure (Fig. 3a). Microstructure of the as-cast $\mathrm{Cu}-25 \% \mathrm{Zn}-4 \% \mathrm{Al}$ alloy includes dendritic $\alpha$ particles with an Fcc structure irregularly distributed in the $\beta$ matrix. As-cast $\mathrm{Cu}-30 \% \mathrm{Zn}$ $4 \% \mathrm{Al}$ alloy has single $\beta$ (Bcc) phase microstructure (Fig. 3b). SEM microphotographs of the investigated alloys in the as-cast states are shown in Fig. 3.

\subsection{Microstructures of the heat treated alloys}

The microstructure of the $\mathrm{Cu}-25 \% \mathrm{Zn}-4 \% \mathrm{Al}$ strip after direct quenching, up-quenching and step-quenching is shown in Figs. 4(a)-(c).

Samples of the $\mathrm{Cu}-25 \% \mathrm{Zn}-4 \% \mathrm{Al}$ alloy strip that were directly quenched into water at room temperature and upquenched show microstructures that are fully martensitic (Figs. $4 \mathrm{a}$ and $4 \mathrm{~b}$ ). Martensitic plates are formed in a V-shape in some grains while they occur needle-like in others ${ }^{12,13}$. However, microstructure of the of the $\mathrm{Cu}-25 \% \mathrm{Zn}-4 \% \mathrm{Al}$ sample that were step-quenched into boiling water for 15 minutes and subsequently cooled in the room temperature water beside martensite phase also includes very fine precipitates of the $\alpha$ phase situated along the grain boundaries and inside the grains (Fig. 4c). The obtained martensitic microstructures are very similar to those reported by Aldirmaz et al. ${ }^{13}$ and De Araújo and Gonzalez ${ }^{14}$ for the alloys with chemical compositions very close to the composition of the $\mathrm{Cu}-25 \% \mathrm{Zn}-4 \% \mathrm{Al}$ alloy.

Fig. 5 shows the microstructures of the $\mathrm{Cu}-30 \% \mathrm{Zn}-4 \% \mathrm{Al}$ alloy after direct quenching, up-quenching and step-quenching.

As it can be seen from Fig. 5 martensite was not obtained in any of the three differently heat treated samples of the $\mathrm{Cu}-30 \% \mathrm{Zn}-4 \% \mathrm{Al}$ alloy. Microstructures of the samples were fully austenite (parent $\beta$ phase), the same as the microstructure of the corresponding alloy in the as-cast condition. Based on the obtained results it can be concluded that the martensite start (Ms) temperature for the $\mathrm{Cu}-30 \% \mathrm{Zn}-4 \% \mathrm{Al}$ alloy is below room temperature.

\subsection{Thermal analysis of heat-treated $\mathrm{Cu}-25 \% \mathrm{Zn}$ - $4 \%$ Al alloy}

Austenite start and finish temperatures (As and Af) for three differently heat-treated samples of the $\mathrm{Cu}-25 \% \mathrm{Zn}$ $4 \% \mathrm{Al}$ strip alloy with identified martensitic structures were determined by means of DSC technique.

DSC study was performed several days after the heattreatments using a SDT Q600 (TA Instruments) simultaneous DSC/TGA analyzer. Samples for the DSC measurements were in the compact thin flat forms which were cut from the heat treated strips. The mass of the investigated samples was about $50 \mathrm{mg}$. DSC measurements were carried out in three heating runs from room temperature to $100^{\circ} \mathrm{C}$ maintaining a constant heating rate of $5^{\circ} \mathrm{C} / \mathrm{min}$.

Fig. 6 shows obtained DSC curves for three heating runs for directly quenched $\mathrm{Cu}-25 \% \mathrm{Zn}-4 \% \mathrm{Al}$ sample with determined austenite start and finish temperatures.

Austenite start temperature (As) was obtained as the temperature of the extrapolated peak onset while the austenite finish temperature (Af) was determined as the peak endset temperature on heating.

Summary results of DSC analysis are presented in Table 1.

From Table 1 it can be seen that the determined austenite transformation temperature intervals span between 30 to $60{ }^{\circ} \mathrm{C}$. Austenite start and finish temperatures are slightly shifted to the higher values after the first heating run in all three cases. Obtained transformation temperatures for

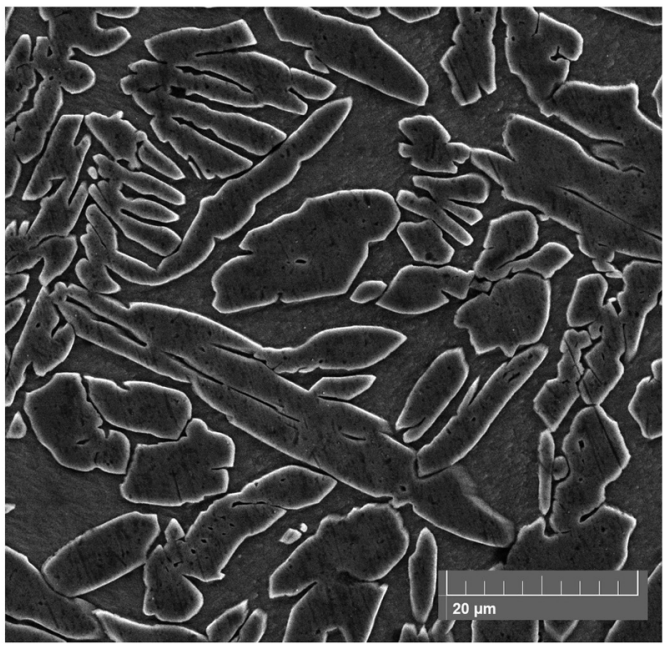

(a)

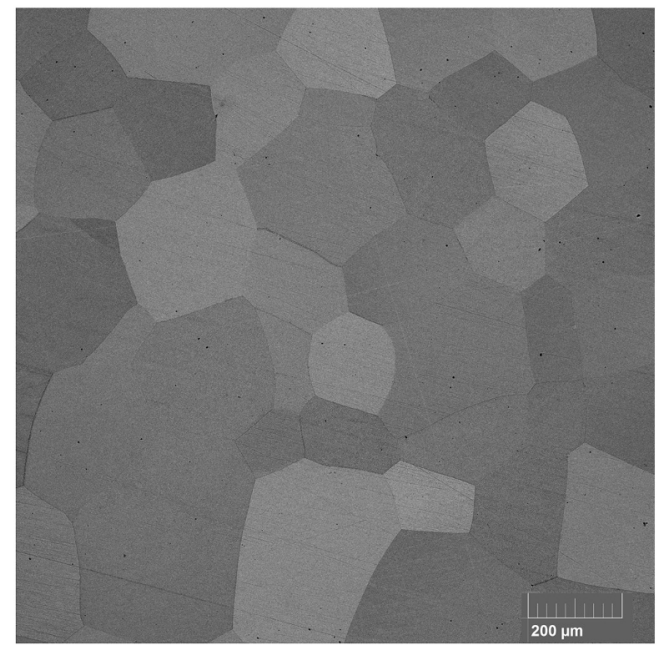

(b)

Figure 3. SEM micrographs of investigated alloys in the as-cast state: (a) $\mathrm{Cu}-25 \% \mathrm{Zn}-4 \% \mathrm{Al}$ alloy, (b) $\mathrm{Cu}-30 \% \mathrm{Zn}-4 \% \mathrm{Al}$ alloy. 


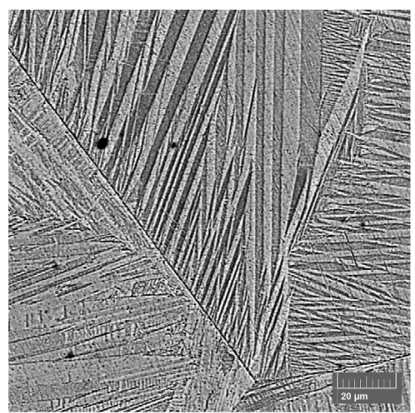

(a)

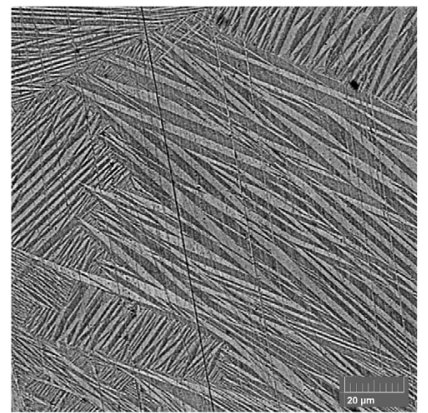

(b)

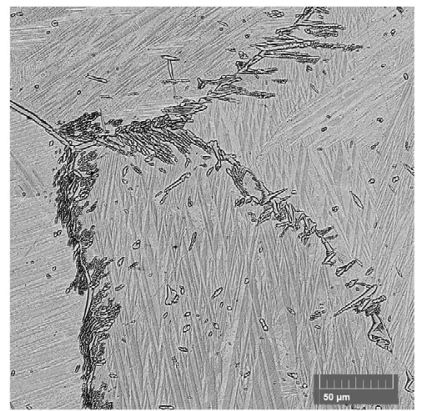

(c)

Figure 4. SEM micrograph of the $\mathrm{Cu}-25 \% \mathrm{Zn}-4 \% \mathrm{Al}$ strip alloy after: (a) direct quenching, (b) up-quenching, (c) step-quenching.

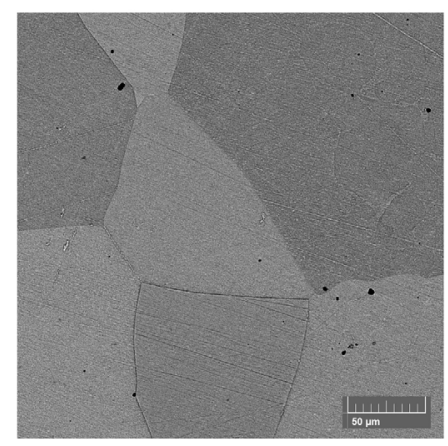

(a)

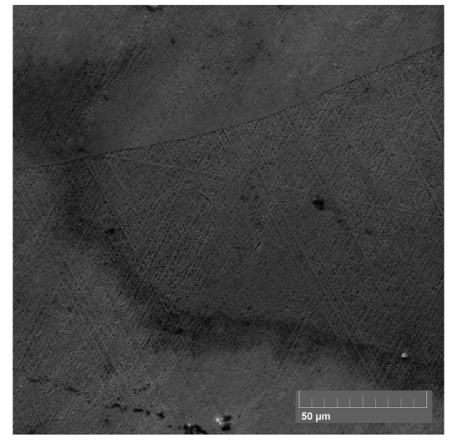

(b)

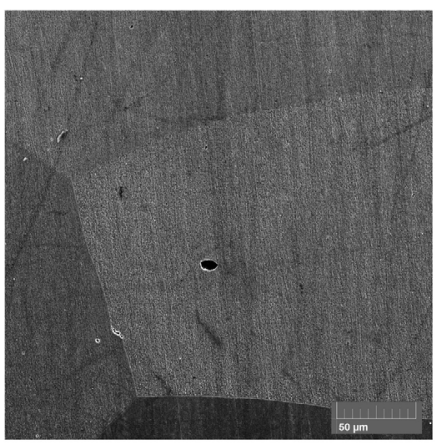

(c)

Figure 5. SEM micrograph of the $\mathrm{Cu}-30 \% \mathrm{Zn}-4 \% \mathrm{Al}$ alloy after: (a) direct quenching, (b) up-quenching, (c) step-quenching. 


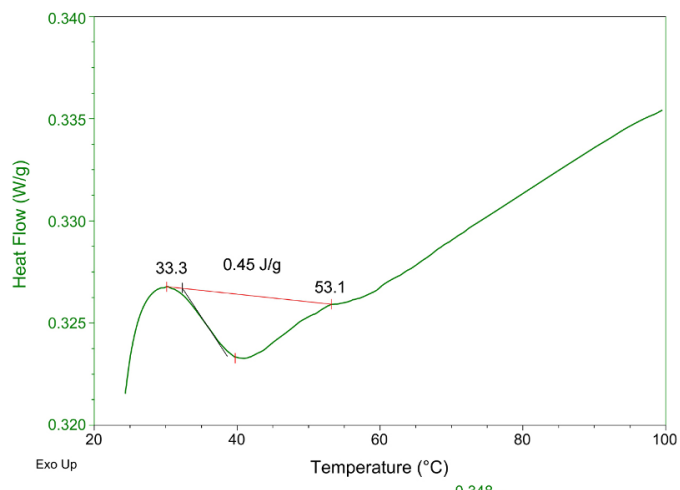

(a)

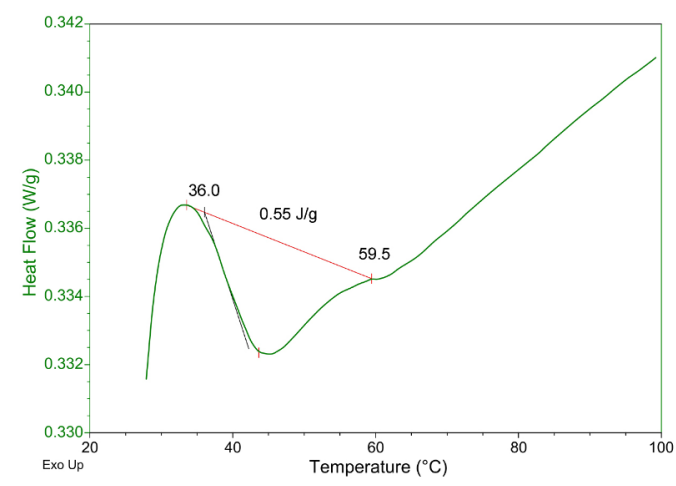

(b)

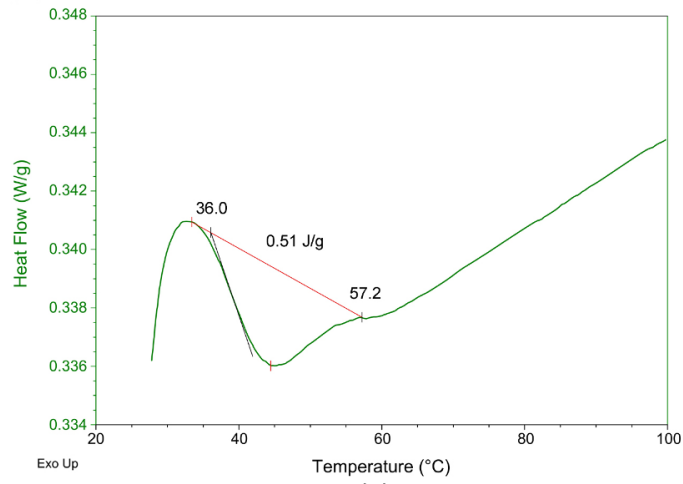

(c)

Figure 6. DSC thermogram for directly quenched $\mathrm{Cu}-25 \% \mathrm{Zn}-4 \% \mathrm{Al}$ alloy first heating run; (b) second heating run; (c) third heating run.

Table 1. Austenite start and finish temperatures and enthalpy of martensite $\rightarrow$ austenite transformation obtained by DSC analysis

\begin{tabular}{|c|c|c|c|c|c|c|c|}
\hline \multirow{3}{*}{ Sample } & \multicolumn{6}{|c|}{ Transformation temperatures $\left({ }^{\circ} \mathrm{C}\right)$} & \multirow{3}{*}{$\begin{array}{l}\text { Average enthalpy of } \\
\text { transformation }(\mathrm{J} / \mathrm{g})\end{array}$} \\
\hline & \multicolumn{2}{|c|}{ 1. heating run } & \multicolumn{2}{|c|}{ 2. heating run } & \multicolumn{2}{|c|}{ 3. heating run } & \\
\hline & As & Af & As & Af & As & Af & \\
\hline 1 (directly quenched alloy) & 33.3 & 53.1 & 36.0 & 59.5 & 36.0 & 57.2 & 0.50 \\
\hline 2 (up-quenched alloy) & 34.2 & 54.3 & 34.8 & 55.7 & 35.2 & 56.3 & 0.49 \\
\hline 3 (step-quenched alloy) & 32.5 & 51.3 & 33.6 & 54.0 & 37.8 & 56.1 & 0.47 \\
\hline
\end{tabular}

the $\mathrm{Cu}-25 \% \mathrm{Zn}-4 \% \mathrm{Al}$ alloy determined in this work are somewhat lower than the results of Oliveira et al. ${ }^{15}$, obtained for the commercial SMA wire with the nominal composition $\mathrm{Cu}-25.3 \% \mathrm{Zn}-4 \% \mathrm{Al}$ and $0.9 \mathrm{~mm}$ diameter, and Prakash and Harchekar ${ }^{16}$, who reported a recovery temperature (As) of about $65{ }^{\circ} \mathrm{C}$ for the $\mathrm{Cu}-26 \% \mathrm{Zn}-4 \% \mathrm{Al}$ alloy wire. Average enthalpy values of austenitic transformations based on the three heating runs were $0.50 \mathrm{~J} / \mathrm{g}$ for directly quenched alloy, $0.49 \mathrm{~J} / \mathrm{g}$ for the up-quenched alloy and $0.47 \mathrm{~J} / \mathrm{g}$ for the step-quenched alloy.

DSC study of the directly quenched $\mathrm{Cu}-25 \% \mathrm{Zn}-4 \% \mathrm{Al}$ alloy has been additionally performed on DSC analyzer Mettler Toledo 822e in two thermal cycles from -50 to 200 ${ }^{\circ} \mathrm{C}$ maintaining a constant heating/cooling rate of $10^{\circ} \mathrm{C} / \mathrm{min}$.

Transformation temperatures obtained on heating were in agreement with the results obtained using SDT Q600 device. However, two distinct exothermic peaks were detected during cooling runs.
Fig. 7 shows DSC curve from the second cooling run. The first transformation is detected as a smaller peak starting at $\mathrm{Ms}=41.9^{\circ} \mathrm{C}$ and finishing at $\mathrm{Mf}=17.0^{\circ} \mathrm{C}$. The second transformation, which starts at $\mathrm{Ms}^{\prime}=10.5^{\circ} \mathrm{C}$ and finishes at $\mathrm{Mf}^{\prime}=-25.1^{\circ} \mathrm{C}$, corresponds to a bigger peak on the DSC curve. These results imply that martensitic transformation occurs in two steps during cooling.

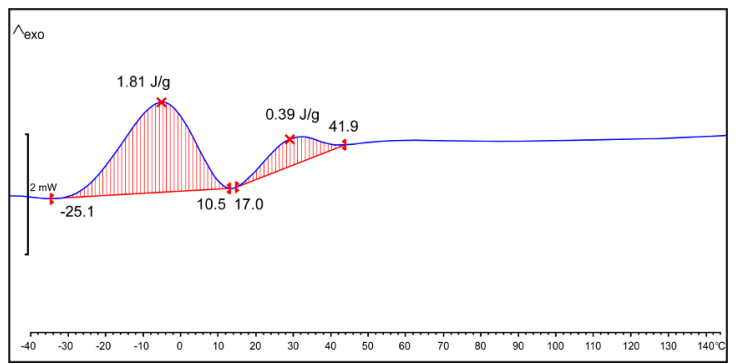

Figure 7. Second DSC cooling run for directly quenched $\mathrm{Cu}-$ $25 \% \mathrm{Zn}-4 \% \mathrm{Al}$ alloy. 


\section{Conclusion}

The effects of heat-treatment on the microstructure and phase transformations of $\mathrm{Cu}-25 \% \mathrm{Zn}-4 \% \mathrm{Al}$ and $\mathrm{Cu}-30 \% \mathrm{Zn}-$ $4 \% \mathrm{Al}$ alloys were investigated in this work. The alloys were prepared by induction melting of pure metals and hot rolled into the $0.5 \mathrm{~mm}$ thick strips. Obtained alloy strips were subjected to three different heat treatment procedures: direct quenching, step-quenching and up-quenching with boiling water and room temperature water as the quenchants.

Based on the results of microstructure and thermal analysis investigations following conclusions can be made:

1) Microstructure of the as-cast $\mathrm{Cu}-25 \% \mathrm{Zn}-4 \% \mathrm{Al}$ alloy consists of $\beta$ phase in the base and a considerable amount of irregular dendritic $\alpha$ particles with an FCC structure distributed in the $\beta$ matrix.

$\mathrm{Cu}-30 \% \mathrm{Zn}-4 \% \mathrm{Al}$ alloy in the as-cast state has singlephase microstructure which includes large polygonal grains of $\beta$ phase.

2) Direct quenching and up-quenching produce fully martensitic microstructure in the $\mathrm{Cu}-25 \% \mathrm{Zn}-4 \% \mathrm{Al}$ alloy. Martensite was also induced by step-quenching, but microstructure of the step-quenched $\mathrm{Cu}-25 \% \mathrm{Zn}-4 \% \mathrm{Al}$ sample also includes small precipitate particles of $\alpha$ phase.

3) Neither one of three heat-treatments performed in this work did not induce martensite in the $\mathrm{Cu}-30 \% \mathrm{Zn}-4 \% \mathrm{Al}$ alloy. These results suggest that the martensite start temperature (Ms) for this alloy is below room temperature.

4) Austenite start and finish transformation temperatures (As, Af) of differently heat-treated $\mathrm{Cu}-25 \% \mathrm{Zn}-4 \% \mathrm{Al}$ alloy were investigated using DSC technique. It was determined that martensite to austenite transformation for the $\mathrm{Cu}$ $25 \% \mathrm{Zn}-4 \% \mathrm{Al}$ alloy occurs in the temperature range from approximately 30 to $60{ }^{\circ} \mathrm{C}$. Comparison between obtained values of As and Af temperatures revealed small influence of applied heat-treatment processes on austenite start and finish temperatures.

5) Two close thermal effects in the temperature interval from 42 to $-25^{\circ} \mathrm{C}$ were detected during the DSC cooling runs of directly quenched $\mathrm{Cu}-25 \% \mathrm{Zn}-4 \% \mathrm{Al}$ alloy. These could be due to the formation of different martensitic structures.

\section{Acknowledgements}

This study was supported by the Ministry of Education, Science and Technological Development, Republic of Serbia, under Project ON 172037. Also, this study was done in the frame of the bilateral project between University of Belgrade, Technical Faculty in Bor (Serbia) and University of Zagreb, Metallurgical faculty in Sisak (Croatia), entitled "Razvoj karakterizacija inovativnih legura sa efektom pamćenja oblika iz sistema $\mathrm{Cu}-\mathrm{Al}-\mathrm{Mn}-\mathrm{Me}(\mathrm{Me}=\mathrm{Ag}, \mathrm{Au}, \mathrm{Ce}) "$. This work has been supported in part by Croatian Science Foundation under the project IP-2014-09-3405.

\section{References}

1. Dasgupta R. A look into Cu-based shape memory alloys: Present scenario and future prospects. Journal of Materials Research. 2014;29(16):1681-1698.

2. Guerioune M, Amiour Y, Bounour W, Guellati O, Benaldjia A, Amara A, et al. SHS of shape memory CuZnAl alloys. International Journal of Self-Propagating High-Temperature Synthesis. 2008;17(1):41-48.

3. Blanco M, Barragan JTC, Barelli N, Noce RD, Fugivara CS, Fernández $\mathrm{J}$, et al. On the electrochemical behavior of $\mathrm{Cu}-$ $16 \% \mathrm{Zn}-6.5 \% \mathrm{Al}$ alloy containing the $\beta^{\prime}$-phase (martensite) in borate buffer. Electrochimica Acta. 2013;107:238-247.

4. Ahlers M. Martensite and equilibrium phases in $\mathrm{Cu}-\mathrm{Zn}$ and $\mathrm{Cu}-\mathrm{Zn}$-Al alloys. Progress in Materials Science. 1986;30(3):135186.

5. Jani JM, Leary M, Subic A, Gibson MA. A review of shape memory alloy research, applications and opportunities. Materials and Design (1980-2015). 2014;56:1078-1113.

6. da Silva MR, Gargarella P, Gustmann T, Botta Filho WJ, Kiminami CS, Eckert J, et al. Laser surface remelting of a $\mathrm{Cu}-\mathrm{Al}-\mathrm{Ni}-\mathrm{Mn}$ shape memory alloy. Materials Science and Engineering: A. 2016;661:61-67.

7. Lojen G, Gojić M, Anžel I. Continuously cast Cu-Al-Ni shape memory alloy - Properties in as-cast condition. Journal of Alloys and Compounds. 2013;580:497-505.

8. Wang Z, Zu X, Fu Y. Review on the temperature memory effect in shape memory alloys. International Journal of Smart and Nano Materials. 2011;2(3):101-119.

9. Asanovic V, Delijic K, Jaukovic N. A study of transformations of ß-phase in $\mathrm{Cu}-\mathrm{Zn}-\mathrm{Al}$ shape memory alloys. Scripta Materialia. 2008;58(7):599-601.

10. Liang SM, Schmid-Fetzer R. Thermodynamic assessment of the Al-Cu-Zn system, Part III: Al-Cu-Zn ternary system. Calphad. 2016;52:21-37.

11. Cao W, Chen SL, Zhang F, Wu K, Yang Y, Chang YA, et al. PANDAT software with PanEngine, PanOptimizer and PanPrecipitation for multi-component phase diagram calculation and materials property simulation. Calphad. 2009;33(2):328-342.

12. Dagdelen F, Gokhan T, Aydogdu A, Aydogdu Y, Adigüzel O. Effects of thermal treatments on transformation behaviour in shape memory Cu-Al-Ni alloys. Materials Letters. 2003;57(56):1079-1085.

13. Aldirmaz E, Celik H, Aksoy I. SEM and X-Ray Diffraction Studies on Microstructures in Cu-26.04\%Zn-4.01\%Al Alloy. Acta Physica Polonica A. 2013;124(1):87-89.

14. De Araújo CJ, Gonzalez CH. A two-stage transformation in $\mathrm{Cu}-\mathrm{Zn}$-Al SMA wires. In: Proceedings of COBEM 2005. $18^{\text {th }}$ International Congress of Mechanical Engineering ; 2005 Nov 6-11; Ouro Preto, MG, Brazil. Available from: <http:// www.abcm.org.br/anais/cobem/2005/PDF/COBEM2005-0079. pdf>. Access in: 25/7/2017. 
15. Oliveira CAN, Gonzalez CH, de Araujo CJ, de Araujo Filho OO, Urtiga Filho SL. Thermoelastic properties on $\mathrm{Cu}-\mathrm{Zn}$-Al shape memory springs. Materials Research. 2010;13(2):219-223.
16. Prakash K, Harchekar VR. Optimisation of rebetatising time and temperature for lowering martensitic transformation temperature in $\mathrm{Cu}-\mathrm{Zn}-4 \%$ A1 shape memory alloy. Indian Journal of Engineering and Materials Sciences. 1997;4(2):67-70. 